\title{
VALUING ASSETS IN RETIREMENT SAVINGS ACCOUNTS
}

James M. Poterba*

CRR WP 2004-11

Released: April 2004

Draft Submitted: March 2004

\author{
Center for Retirement Research at Boston College \\ 550 Fulton Hall \\ 140 Commonwealth Ave. \\ Chestnut Hill, MA 02467 \\ Tel: 617-552-1762 Fax: 617-552-1750 \\ http://www.bc.edu/crr
}

* James Poterba is the Mitsui Professor of Economics at the Massachusetts Institute of Technology. The research reported herein was performed pursuant to a grant from the U.S. Social Security Administration (SSA) to the Center for Retirement Research at Boston College (CRR). The opinions and conclusions are solely those of the author and should not be construed as representing the opinions or policy of the SSA or any agency of the Federal Government or of the CRR. The author would like to thank Rosanne Altshuler, Dan Beller, Len Burman, Roger Gordon, Laurence Kotlikoff, David McCarthy, Joseph Piacentini, William Reichenstein, an anonymous referee, and especially William Gale and William Jennings for helpful comments, and to Daniel Bergstresser, Sarah Siegel, and Amir Sufi for excellent research assistance.

(C) 2004, by James M. Poterba. All rights reserved. Short sections of text, not to exceed two paragraphs, may be quoted without explicit permission provided that full credit, including $\odot$ notice, is given to the source. 


\section{About the Center for Retirement Research}

The Center for Retirement Research at Boston College, part of a consortium that includes parallel centers at the University of Michigan and the National Bureau of Economic Research, was established in 1998 through a grant from the Social Security Administration. The goals of the Center are to promote research on retirement issues, to transmit new findings to the policy community and the public, to help train new scholars, and to broaden access to valuable data sources. Through these initiatives, the Center hopes to forge a strong link between the academic and policy communities around an issue of critical importance to the nation's future.

\section{Center for Retirement Research at Boston College}

550 Fulton Hall

140 Commonwealth Ave.

Chestnut Hill, MA 02467

phone: 617-552-1762 fax: 617-552-1750

e-mail: crr@bc.edu

http://www.bc.edu/crr

Affiliated Institutions:

American Enterprise Institute

The Brookings Institution

Massachusetts Institute of Technology

Syracuse University

Urban Institute 


\begin{abstract}
$\underline{\text { Abstract }}$
Assets in retirement saving plans have become an important component of net worth for many households. While many studies compare household balances in tax-deferred retirement accounts such as 401(k) plans with the financial assets held outside these accounts, these different asset components are not directly comparable. Taxes and in some cases penalties are due when assets are withdrawn from some retirement saving plans. These factors can make a dollar held inside a retirement account less valuable than a dollar held in a similar asset outside these accounts, particularly for those who are considering withdrawing assets from the tax-deferred accounts in the near future. For younger households who do not plan to withdraw tax deferred assets for many years, the opportunity for tax-free compound returns in retirement accounts can make a dollar inside such an account more valuable than a dollar outside such accounts from the standpoint of providing retirement resources, even though the principal from the retirement account will be taxed at the time of distribution, while the principal outside such accounts is untaxed. This paper illustrates the potential differences in the value of a dollar of invested in a bond, or in corporate stock, inside and outside tax-deferred accounts. It draws on a range of data sources to calibrate the value of the tax burden, and the benefit of compound growth, for assets held in retirement accounts, and describes the differences in relative valuation for households of different ages.
\end{abstract}


The rising importance of assets in tax-deferred accounts has changed the way U.S. households prepare for retirement. Assets in Individual Retirement Accounts and 401(k) plans, which have only been widely available since the early 1980s, exceeded four trillion dollars at the end of 2001. Projections such as those in Poterba, Venti, and Wise (2000) suggest that if current contribution patterns persist and if asset returns follow historical patterns, then assets in retirement saving accounts will grow to become an even more significant part of household wealth in the next three decades.

A substantial literature has addressed the question of whether households change their saving behavior outside tax-deferred accounts when they make 401(k) or IRA contributions. The earliest strands of this literature focused on testing whether the stock of financial assets held by households with tax-deferred accounts was lower than that held by similar households without such accounts. Studies in this tradition include Engen and Gale (2000), Engen, Gale, and Scholz (1996), and Poterba, Venti, and Wise (1996, 1998). These studies analyzed whether contributions to tax-deferred accounts reduced assets held in traditional taxable accounts dollar-for-dollar, or by a smaller amount. While many of the early discussions of retirement saving plans suggested that contributions to these plans would crowd-out a substantial amount of other private saving, most of the empirical literature points to substantial new saving associated with these plans. An implicit premise of the empirical tests that emphasize dollar-for-dollar crowd-out is that one dollar held in a tax-deferred account is equivalent to one dollar held in a taxable account.

Several previous studies have recognized the need to consider deferred tax liabilities in comparing the value of assets in tax-deferred accounts with assets held outside such accounts. Reichenstein (1998) and Reichenstein and Jennings (2003) emphasize the need to adjust the value of assets in retirement accounts when constructing a tax-inclusive measure of household net worth or evaluating preparation for retirement. They propose simple adjustments based on the marginal tax rate that a household will face after retirement. Gale (1998) develops a similar insight in his study of 
employer-provided pensions and household saving. He estimates the decrease in household saving outside retirement accounts that would keep a household on the same lifetime indifference curve after an increase in retirement saving as before, thereby recognizing the key differences between assets held in taxable and tax-deferred accounts. Most recently, Sibley (2002) analyzes the current, after-tax value of assets in tax-deferred accounts for various saving hor izons and rates of return, although without investigating the actual distribution of tax-deferred investors across tax brackets or age groups.

Taxes generate differences in the potential value of assets inside and outside tax-deferred retirement accounts. For traditional IRAs and for 401(k) and 403(b) plans, taxes and in some cases penalties are due when assets are withdrawn from retirement accounts. When the tax rates on withdrawals from tax-deferred accounts are different than the tax rates on accumulation outside these accounts, as in the case of a capitalgain producing asset considered by Crain and Austin (1998), the incentive to save through a tax deferred account can depend on household circumstances. Gokhale and Kotlikoff (2003) note that for some households, the applicable tax rates when assets are withdrawn from a retirement account may be greater than those that applied when the funds were contributed to the account. In this case a household may actually be worse off contributing to such an account than saving in a taxable account.

The deferred taxes that can make a dollar held inside a retirement saving account worth less at retirement than a dollar held in a similar asset outside such an account are offset, particularly for long-horizon savers, by the fact that assets in retirement saving accounts can grow tax-free until the time of withdrawal. This "inside build up" can make the retirement resources generated by a dollar held inside a tax-deferred account more valuable than a dollar outside such an account, particularly if the account holder has a long investment horizon. For Roth IRAs, which do not face deferred tax liabilities because contributions were made with after-tax dollars, inside-build up unambiguously makes one dollar inside such an account worth more than one dollar held outside. 
This paper presents simple calculations that compare the value of one dollar held inside, and outside, tax-deferred retirement accounts that were funded with pre-tax contributions. The central question underlying this analysis is how much an individual needs at various ages, outside a 401(k)type plan, to provide the same level of retirement income support that a dollar inside a 401(k) could provide. The answer depends upon a range of assumptions, including how long the assets will be held in the retirement account, how the assets will be drawn down during retirement, what rate of return the asset will earn, how the account holder's tax rate will evolve through time, and what tax rules will apply to withdrawals. The paper notes, but does not report detailed calculations about the possibility of leaving retirement account assets to future generations. With well-advised estate planning, it is possible to extend the time period over which assets can accumulate in tax-deferred accounts by deferring withdrawal well beyond the life expectancy of the original contributor.

The paper is divided into five sections. Section one presents simple calculations that illustrate how a dollar held inside a tax-deferred account can generate more, or less, retirement income support than a dollar invested in the same asset but held outside the tax-deferred account. It focuses on the case of bonds held in either location. This section develops the analyticalframework that underlies the calculations throughout the paper. Section two repeats the analysis for the case of equity investments, and presents results on the relative valuation of stocks held in tax deferred accounts and in traditional taxable accounts. The third section reports summary information on the distribution of assets held in retirement accounts by age and marginal federal income tax rate of the household head, and by asset allocation between stocks and bonds. This information is then used to develop aggregate caculations of the average relative value of the assets in tax-deferred accounts and taxable accounts. The fourth section describes the current tax rules that govern withdrawals from tax-deferred accounts and explains how they can be incorporated in the analysis. It demonstrates how households with tax-deferred accounts can increase the value of tax-deferred accumulation by delaying withdrawals until late in their own life, or by arranging to bequeath assets in their tax- 
deferred accounts to younger relatives. A brief conclusion sketches several directions for further work, and notes several elements of the calculations that could be improved by future empirical research.

$\underline{\text { 1. Valuing Bonds Held in Tax-Deferred Accounts }}$

The central element in any comparison of the value of the retirement income support that can be generated by a dollar held in a taxable account and a dollar held in a traditional tax-deferred account (TDA) such as an IRA or a 401(k) plan is the trade-off between the deferred taxes that will be due on withdrawal from the TDA, which reduce the value of assets in these accounts, and the benefits of tax-free accumulation on TDA assets. This trade-off does not exist for some classes of tax-deferred accounts, such as Roth IRAs, for which there are no future taxes due.

The present paper focuses on the tradeoff for traditional TDAs, which can be illustrated by considering an individual who is $a$ years old and who holds interest-bearing bonds worth $\mathrm{D}(a)$ in a tax-deferred account. Assume that the TDA was funded with pretax contributions, so that when funds are withdrawn from the account, all of the proceeds will be fully taxable at the individual's ordinary income tax rate. Assume further that there is a fixed age A at which the individual plans to withdraw all of the assets from the retirement account, so that the investment horizon is $\mathrm{A}-a$.

This paper considers how much wealth the individual would need to hold in bonds outside a TDA to generate the same after-tax wealth at age A that holding $\mathrm{D}_{\text {bond }}(a)$ in bonds within the TDA will provide. Assume for simplicity that the individual's tax rate on the interest and dividend income is constant through time, at least until retirement. The tax rate that applies to withdrawals from the tax-deferred account may differ from the tax rate during the accumulation phase. Let the tax rate on interest income received during the accumulation phase equal $\tau$, and let $\tau_{\mathrm{A}}$ denote the marginal tax rate when the assets are withdrawn from the tax-deferred account. Let $r$ represent the instantaneous rate of return on bonds, and assume that all of this return comes in the form of interest payments. 
Further assume that the return on bonds is the same, regardless of whether the bonds are held in the taxable or the tax-deferred account.

A tax-deferred account with a bond worth $\mathrm{D}_{\text {bond }}(a)$ at age $a$ will grow to $\mathrm{D}_{\text {bond }}(\mathrm{A})$ at age $\mathrm{A}$, where

$$
\mathrm{D}_{\text {bond }}(\mathrm{A})=\mathrm{D}_{\text {bond }}(a) * \mathrm{e}^{\mathrm{r}(\mathrm{A}-a)}
$$

Since withdrawals from the TDA are fully taxable, its after-tax value is $\left(1-\tau_{A}\right) * D_{\text {bond }}(A)$.

Now consider a bond worth $\mathrm{W}_{\text {bond }}(a)$ that is held in a taxable account at age $a$. The bond earns interest at the after-tax rate of (1- $\tau)$ r, so that by age $A$, its value will be

$$
\mathrm{W}_{\text {bond }}(\mathrm{A})=\mathrm{W}_{\text {bond }}(a)^{*} \mathrm{e}^{(1-\tau) \mathrm{r}^{*}(\mathrm{~A}-a)} .
$$

For the taxable account to be worth $\left(1-\tau_{\mathrm{A}}\right) * \mathrm{D}_{\text {bond }}(\mathrm{A})$ at age $\mathrm{A}$, the individual needs to hold a bond worth $\mathrm{W}^{\prime}$ bond $(a)$ at age $a$, where $\mathrm{W}^{\prime}$ bond $(a)$ satisfies

$$
\left(1-\tau_{\mathrm{A}}\right) * \mathrm{D}_{\text {bond }}(a)^{*} \mathrm{e}^{\mathrm{r}(\mathrm{A}-a)}=\mathrm{W}^{\prime}{ }_{\text {bond }}(a) * \mathrm{e}^{(1-\tau) \mathrm{r}^{*}(\mathrm{~A}-a)} .
$$

This expression can be solved for the ratio $\mathrm{W}^{\prime}$ bond $(a) / \mathrm{D}_{\text {bond }}(a)$, which is the amount of bonds that would need to be held in the taxable account to generate the same after-tax wealth at age A as a onedollar bond investment in the TDA. This ratio, the "equivalent taxable wealth" or $\mathrm{E}_{\mathrm{bond}}(a)$, is:

$$
\mathrm{E}_{\text {bond }}(a)=\mathrm{W}^{\prime} \text { bond }(a) / \mathrm{D}_{\text {bond }}(a)=\left(1-\tau_{\mathrm{A}}\right) * \mathrm{e}^{\tau \mathrm{r}^{*}(\mathrm{~A}-a)} .
$$

Equivalent taxable wealth is increasing in the investment horizon, A- $a$, and in the asset's rate of return (r). The derivative of equivalent taxable wealth with respect to the marginal tax rate is ambiguous, however, in the case with $\tau=\tau_{\mathrm{A}}$. At low marginal tax rates, raising the marginal tax rate raises equivalent taxable wealth, because it makes the value of tax-deferred accumulation greater. At high marginal tax rates, however, the after-tax rate of accumulation is low, and the dominant effect of an increase in the marginal tax rate is a reduction in the value of the tax-deferred account through a higher tax rate on withdrawals. 
When the investment horizon shrinks to zero, so that the individual is comparing the value of TDA assets that are about to be withdrawn with the value of assets held outside the TDA, A $=a$ and $\mathrm{E}_{\text {bond }}(a)=(1-\tau)$. With a long enough investment horizon, and high enough returns, it is possible for $\mathrm{E}_{\mathrm{bond}}(a)$ to be greater than 1 . This can be illustrated by calculating $\mathrm{E}_{\mathrm{bond}}(a)$ for a variety of different parameter values.

Table 1 reports equivalent taxable wealth values for nominal interest rates of four, six, and eight percent per year. Current long-term interest rates are at the lower end of this range for both government and highly-rated corporate bonds. The calculations consider three different marginal tax rates: 15,28 , and 36 percent, which correspond to rates in the federal income tax schedule that prevailed between 2001 and 2003. The analysis focuses only on federal income tax rates; including state tax rates would increase applicable marginal tax rates, although by different amounts for different households. The first set of results assumes that $\tau=\tau_{\mathrm{A}}$. Rather than assuming a particular retirement age, the table considers individuals with retirement horizons that range between zero and fifty years. Fifty years may seem like an excessive horizon for all but the youngest contributors to retirement plans. However, current provisions for minimum distributions from retirement plans allow individuals and married couples who reach retirement age with tax-deferred assets to postpone withdrawal of a substantial share of those assets until they are in their eighties.

The upper panel of Table 1 presents the results of evaluating equation (4) for $\mathrm{E}_{\mathrm{bond}}(a)$. The findings show that the equivalent taxable wealth varies substantially as a function of the rate of return, tax rate, and investment horizon. The table also shows that for all but one of the parameter combinations that include an investment horizon of at least thirty years, $\mathrm{E}_{\text {bond }}(a)$ is greater than unity. Entries for which $\mathrm{E}_{\mathrm{bond}}(a)$ exceeds unity are shown in bold type in the table. For a person with a planning horizon of thirty years, for example, a dollar's worth of bonds held within the tax-deferred account (TDA) is worth at least as much as a dollar of fixed income assets held in a taxable account 
except in the case with a high marginal tax rate $(\mathrm{t}=.36)$ and a low interest rate $(\mathrm{r}=.04)$. With a high rate of return and a high tax rate, $\mathrm{t}=.36$ and $\mathrm{r}=.08$, a dollar held in a tax-deferred account will generate as much retirement wealth in thirty years as 1.52 dollars held in a taxable account. For a fifty year horizon and the same tax rate and interest rate combination, a dollar in a TDA is as valuable as 2.70 dollars held outside such an account. At horizons longer than thirty years, a dollar of fixed-income assets in a tax-deferred account will generate more after-tax wealth at retirement than a dollar in a taxable account, even though taxes have already been paid on the investment principal outside the TDA. The results in Table 1 are sensitive to assumptions about interest rates. At low interest rates, the deferral horizon needs to be longer to make tax-deferred assets at least as valuable as assets held outside the TDA.

The calculations in the upper panel of Table 1 assume that the marginal income tax rate that applies to the accruing interest on the bond held outside the TDA is the same as the income tax rate that applies to withdrawals from the TDA. For some households, however, marginal tax rates may differ before and after retirement. For households with lower income levels in retirement, marginal tax rates may fall after retirement, while for others, marginal tax rates may rise. The next two panels of Table 1 consider these possibilities.

Lower tax rates in retirement than while working raise the relative value of assets held in the tax-deferred account, because the accruing income on the underlying assets is not only taxed later, but also at a lower rate, as a consequence of its position in the TDA. A decline in marginal tax rates after retirement also makes it more attractive to contribute to a TDA, since contributions avoid taxation at a high marginal tax rate but are taxed at a low marginal rate when they are withdrawn in retirement.

The middle and lower panels of Table 1 extends the calculation of equivalent taxable wealth by allowing for differences between the marginal tax rate on withdrawals $\left(\tau_{\mathrm{A}}\right)$ and accruing interest 
$(\tau)$. In the middle panel, the value of $\tau_{\mathrm{A}}$ is set to 0.15 , the lowest marginal tax bracket on ordinary income. The entries that assume $\tau=.15$ are the same in the upper panel and in the middle panel. For the cases of $\tau=.28$ and $\tau=.36$, however, the equivalent taxable wealth values in the lower panel are greater than the values in the upper panel. In some cases the differences are substantial. For example, in the case of $\tau=.36$ with $\mathrm{r}=.06$, the value of $\mathrm{E}_{\mathrm{bond}}(a)$ rises from 1.52 to 2.02 at a 40 year horizon, and from 1.89 to 2.50 at a 50 year horizon.

Gokhale and Kotlikoff (2003) and Gokhale, Kotlikoff, and Neumann (2001) note that for some retirement savers, marginal tax rates may be higher after retirement than before. This case is particularly likely for households that have substantial income tax deductions while they are working, that earn high returns in their retirement accounts, and that face taxation of their Social Security benefits when they retire. This could also happen if an individual withdraws assets from the TDA prior to reaching age $59 \frac{1}{1} 2$. In this case, the withdrawal is subject to ordinary income taxation, and there is an additional ten percent penalty tax. To allow for this possibility, the lower panel of Table 1 assumes that the tax rate on withdrawals is ten percentage points higher than the tax rate on interest income during the household's accumulation phase.

The results show that the higher tax rate on withdrawals raises the holding period at which a dollar invested in a bond in a TDA generates the same retirement support as a dollar invested in a bond in a traditional taxable account. In only five of nine parameter combinations that we consider for a horizon of thirty years does the value of a one dollar bond investment in a TDA exceed the value of a similar bond outside a TDA. Even for a forty year horizon, if the interest rate is assumed to be four percent, a one dollar bond investment outside the TDA will purchase more retirement income than a similar bond investment within a TDA. For higher interest rate values, a one dollar investment in a TDA is clearly more valuable than an equivalent taxable investment, as a result of the power of compound appreciation. 
The calculations in Table 1 provide information on the relative value, measured in terms of retirement income support, of assets held inside and outside a TDA. The calculations apply to assets that have already been contributed to either a taxable or a tax-deferred account. These calculations can also be used to provide some information on the attractiveness of contributing to a tax-deferred account. Consider an individual who can allocate one dollar of current earnings either to a taxdeferred account, where it can be used to purchase one dollar of assets, or to a taxable account, where it can be used to purchase (1- $\tau)$ dollars of assets. Comparing $\mathrm{E}_{\mathrm{bond}}(a)$, the current value of one dollar in a TDA, and (1- $\tau)$, the current value of one dollar earned, taxed, and contributed to a taxable account, illuminates the desirability of contributing to a tax-deferred account. When $\mathrm{E}_{\mathrm{bond}}(a)>(1-\tau)$, contributing to the TDA will yield more retirement income support than saving outside the TDA.

Consider the application of this rule in the upper panel of Table 1. All of the entries for $\mathrm{E}_{\text {bond }}(a)$ are at least as great as $(1-\tau)$, with strict equality only when the deferral horizon is zero. Thus in all cases households would find that contributing to a tax-deferred plan would increase the level of wealth available to support retirement consumption relative to saving the same pre-tax earnings outside a TDA. The conclusion that contributing to the tax-deferred account raises the household's available wealth at retirement would be strengthened if the household participated in a retirement plan that was eligible for corporate matching contributions. This is often the case in $401(\mathrm{k})$ plans. In this case, contributing a dollar to the TDA would increase the value of retirement wealth whenever $(1+\mathrm{m}) * \mathrm{E}_{\mathrm{bond}}(a)>(1-\tau)$, where $\mathrm{m}$ denotes the corporate match rate on employee contributions.

2. Equivalent Taxable Wealth for Equities Held in Taxable and Tax-Deferred Accounts

The foregoing calculations compare bond investments that could be held inside, or outside, a tax-deferred account. Yet bonds account for only half of the assets in tax-deferred accounts - the remaining assets are held in corporate stock. Some of these investments are direct stock holdings, while others are investments through equity mutual funds. The tax burden on corporate stock, when 
held in a taxable account, is substantially lower than the tax burden on interest-bearing assets. This has been true historically because part of the return on equities comes in the form of less-heavilytaxed capital gains. The lower tax burden on the returns on equity investments, relative to the tax on withdrawals from TDAs, affects the equivalent wealth calculation.

To develop equivalent wealth estimates for corporate stock investments, consider an individual who holds equity with an expected return of $r_{s}=d+g$, where d denotes the dividend payout and $\mathrm{g}$ is the capital gain or loss. Again assume that these are instantaneous rates of return, since over discrete intervals it becomes necessary to consider the "reinvestment return" on dividends, and the total return may therefore differ from the sum of the dividend yield and the capital gain. Let $\tau_{\mathrm{cg}}$ denote the statutory tax rate on realized capital gains and $\tau_{\text {div }}$ the marginal tax rate on dividend income. If the stock is purchased in year a, so that the purchase basis for the stock is $\mathrm{W}_{\text {equity }}(a)$, then the after-tax value of a zero-dividend stock's shares after (A- $a$ ) years will be

$$
\mathrm{W}_{\text {equity }}(\mathrm{A})=\mathrm{W}_{\text {equity }}(a)^{*}\left[\mathrm{e}^{\mathrm{g}(\mathrm{A}-a)}-\tau_{\mathrm{cg}} *\left(\mathrm{e}^{\mathrm{g}(\mathrm{A}-a)}-1\right)\right]
$$

This expression assumes that none of the initial holdings are liquidated until A- $a$ years after the purchase.

If the stock pays a dividend of $\mathrm{d}$ and the individual re-invests the after-tax proceeds from each year's dividends, $\mathrm{d}^{*} \mathrm{~W}_{\text {equity }}(\mathrm{t})$, there will be additional shares at time $\mathrm{A}$ that are attributable to these purchases. In this case, the total market value of the in dividual's holdings in the stock will grow at the annual rate $\mathrm{g}+\left(1-\tau_{\mathrm{div}}\right) * \mathrm{~d}$, and the after-tax value at age $\mathrm{A}$ will be

$$
\left.\mathrm{W}_{\text {equity }}(\mathrm{A})=\mathrm{W}_{\text {equity }}(a)^{*}\left[\mathrm{e}^{(\mathrm{g}+(1-\tau) \operatorname{div}}\right) *(\mathrm{~A}-a) *\left(1-\tau_{\text {cg }}\right)\right]+\tau_{\text {cg }} * \mathrm{~B}\left(\mathrm{~A}, \mathrm{~W}_{\text {equity }}(a)\right) .
$$

$\mathrm{B}\left(\mathrm{A}, \mathrm{W}_{\text {equity }}(a)\right)$ denotes the individual's tax basis in the stock, which evolves according to the differential equation

$$
\left.\partial \mathrm{B}(\mathrm{t}) / \partial \mathrm{t}=\mathrm{d}^{*}\left(1-\tau_{\text {div }}\right) * \mathrm{~W}_{\text {equity }}(\mathrm{t})=\mathrm{d}^{*}\left(1-\tau_{\text {div }}\right) * \mathrm{e}_{\text {div }}^{(\mathrm{g}+(1-\tau)}\right) *(\mathrm{t}-a) * \mathrm{~W}_{\text {equity }}(a) .
$$

Solving this equation, using the initial condition $\mathrm{B}(a)=\mathrm{W}_{\text {equity }}(a)$, and evaluating at age A yields 


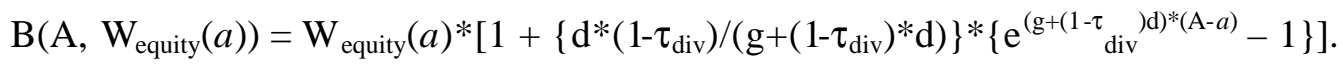

Substituting (8) into (6) makes it possible to evaluate the after-tax value of a taxable position in corporate stock, subject to reinvestment of dividends.

The value at age $\mathrm{A}$ of a tax-deferred account worth $\mathrm{D}_{\text {equity }}(a)$ at age $a$ and fully invested in equities is more straightforward to compute than the value of a comparable taxable account. Assuming that divide nds have been reinvested and that all assets are withdrawn at age A, the aftertax value of the equity investment is $\left(1-\tau_{\mathrm{A}}\right) * \mathrm{D}_{\text {equity }}(a)^{*} \mathrm{e}^{(\mathrm{g}+\mathrm{d})(\mathrm{A}-a)}$. Note that the tax rate that applies in this expression is the ordinary income tax rate at the time of withdrawal, $\tau_{\mathrm{A}}$. This is the key tax parameter that affects the value of the tax-deferred account balance. Now W' equity $(a)$, the equivalent taxable wealth in the equity case, must satisfy

$$
\mathrm{W}^{\prime}{ }_{\text {equity }}(a)^{*}\left[\mathrm{e}_{\text {div }}^{\left(\mathrm{g}+\left(1-\tau^{\prime}\right) *(\mathrm{~A}-a)\right.} *\left(1-\tau_{\mathrm{cg}}\right)\right]+\tau_{\mathrm{cg}} * \mathrm{~B}\left(\mathrm{~A}, \mathrm{~W}^{\prime} \text { equity }(a)\right)=\left(1-\tau_{\mathrm{A}}\right) * \mathrm{D}_{\text {equity }}(a) * \mathrm{e}^{(\mathrm{g}+\mathrm{d}) *(\mathrm{~A}-a)} .
$$

Solving this expression yields

$$
\mathrm{E}_{\text {equity }}(a)=\mathrm{W}^{\prime} \text { equity }(a) / \mathrm{D}_{\text {equity }}(a)
$$

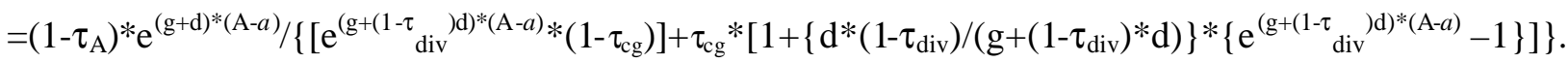

The Jobs and Growth Tax Relief Reconciliation Act of 2003 (JGTRRA) reduced the investor tax burden on dividends and capital gains from investments held outside a tax-deferred account. While the law capped both $\tau_{\mathrm{cg}}$ and $\tau_{\text {div }}$ for stocks at fifteen percent, it did not change the rule that withdrawals from tax-deferred accounts are taxed as ordinary income. This legislation consequently reduces the tax burden on assets outside the TDA, while not changing the tax treatment of TDA assets, so it reduces the value of TDA assets relative to assets held outside these accounts. The tax relief for dividends and capital gains enacted in 2003 is scheduled to expire after several years, so the numerical results discussed below consider cases with and without this reduction in equity tax rates. 
To evaluate the equivalent taxable wealth for stocks, it is necessary to choose an equity rate of return. Historical return experience would suggest nominal return values of roughly 12 percent per year. A number of contemporary analyses, however, such as Campbell (2001), Diamond (2001), and Shoven (2001), suggest that the equity premium is likely to be somewhat smaller in future decades than in the past. The calculations reported below therefore consider equity returns of six, nine, and twelve percent per year. In each case, the dividend yield is fixed at two percent per year, so the variation in expected returns is reflected in different expected capital appreciation rates. The expected returns throughout this paper are reported in nominal terms, since the tax system applies to nominal interest, dividends, and capital gains.

Table 2 reports equivalent taxable wealth values for equity investments, under various assumptions about the relationship between the ordinary income tax rate and the statutory capital gains tax rate. The table considers four tax regimes, three corresponding to the pre-JGTRRA environment and one assuming that JGTRRA is extended and remains in force forever. The first is for an individual in the 15 percent marginal tax rate bracket for dividend income, and in the 7.5 percent long-term capital gains tax bracket. This corresponds to a low-income household in the years following the 2001 tax reform but prior to the enactment of the 5 percent and 15 percent marginal tax rates in 2003. The capital gains tax rate of 7.5 percent is set to recognize that deferral of gains can reduce the effective capital gains tax burden to roughly half its statutory rate, as discussed in Poterba (1998). The second case includes an ordinary income tax rate of 28 percent, and a capital gains tax rate of 10 percent. The capital gains tax rate corresponds to half of the statutory rate of 20 percent on long-term gains for an investor in the 28 percent ordinary income tax bracket. The third case assumes an ordinary income tax rate of 36 percent, again with a 10 percent capital gains tax rate. Finally, the fourth case considers a situation with a 15 percent marginal tax rate on both dividends and capital gains, and a marginal tax rate of 35 percent on ordinary income such as interest and distributions from tax-deferred accounts. The third and fourth cases correspond to the situations 
facing a high-income taxpayer in 2002, prior to the enactment of JGTRRA, and in 2004, after enactment of the tax reform and assuming that the relevant tax rates stay in force forever.

The three horizontal panels of Table 2 are comparable to those pertaining to bond investments in Table 1. The upper horizontal panel assumes that withdrawals from the tax-deferred account are taxed at the individual's ordinary income tax rate during the accumulation phase. The middle horizontal panel applies a lower marginal tax rate of 15 percent to withdrawals, and the bottom panel assumes that the marginal tax rate in retirement is ten percentage points higher than the ordinary income tax rate while working and accumulating.

The results in Table 2 suggest that when individual holds equities rather than bonds, a dollar invested through a TDA is less valuable, relative to a dollar invested outside a TDA. This is particularly true if JGTRRA remains in force. Consider first the three vertical panels that relate to the pre-JGTRRA situation. In the upper horizontal panel of Table 2, the investor needs an accumulation horizon of forty years in the low marginal tax rate case $(t=.15)$, and fifty years with the higher marginal tax rates, before a one dollar equity investment inside a tax-deferred account is worth more than a one dollar equity investment outside a taxable account.

The relative value of TDA assets is greater in the middle horizontal panel, which assumes that withdrawals are taxed at a marginal tax rate of 15 percent. In this case, when the dividend tax rate is 28 percent or higher, even a twenty year investment horizon is sufficient to allow a dollar in the TDA to generate as much retirement income support as a dollar invested in equities in a taxable account. At very long horizons, such as 50 years, a dollar in the TDA may generate retirement support as much as thirty percent greater than a dollar in a taxable account.

The bottom panel of Table 2 considers the case of a higher tax burden on withdrawals from the tax-deferred account than on labor income during the working life. In this case, a dollar held inside a TDA is worth less than a dollar of stock in a taxable setting, typically by a substantial margin. Because equities are assumed to yield only a small part of their return in the form of 
dividend payments, the additional tax burden associated with facing ordinary income tax rates, plus penalty taxes, when withdrawing assets from the TDA represents a very substantial increase relative to the primarily capital gains tax burden on equity returns outside tax-deferred accounts.

The right-most vertical panel of Table 2 presents results for the post-JGTRRA setting. The reference individual in this case is a high-income taxpayer with a 35 percent ordinary income tax rate but a 15 percent marginal tax rate on dividend income and a 7.5 percent effective tax rate on accruing capital gains. The results suggest that the enactment of JGTRRA reduced the value of a dollar held in stocks in a TDA relative to the value of a dollar held in stocks outside a tax-deferred account. Consider the findings in the uppermost horizontal panel, which assumes that the ordinary income tax rate in retirement is the same as that while working. For a thirty year horizon and a nine percent equity return, the equivalent wealth value was 0.861 when the ordinary income tax rate of 36 percent both applied to dividends and withdrawals from the TDA, and the effective capital gains tax rate was 7.5 percent. This corresponds to the tax environment of 2002. The equivalent wealth value drops to 0.753 for the comparable return assumptions under the post-2003 tax rules, when dividends face a 15 percent tax rate. Lengthening the investment horizon has a smaller effect on the relative value of taxdeferred and taxable assets in the post-JGTRRA setting than before, because the after-tax rate of return on equities inside the TDA is nine percent, while that on equities outside the TDA is .09 $.075 *(.07)-.15 * .02$, or 8.175 percent. This is a smaller differential between the rate of return inside and outside the TDA than in many of the other cases considered in Tables 1 and 2.

The bottom panel in the last vertical column of Table 2 shows the effect of combining a ten percent penalty tax on withdrawals from the TDA with the post-JGTRRA tax rate environment for high-income taxpayers. In this setting, not only is the equivalent wealth value always below unity, it is even below (1-t) for all but the longest investment horizons. For example, with an equity return of nine percent, it now takes almost forty years of tax-deferred accumulation for one dollar held in a TDA to be able to generate the same after-tax income at retirement as a (1-t) dollars held in a taxable 
account. Recall that the comparison between (1- $\tau)$, the amount that a household receives net of labor income taxes from one dollar of earnings, and $\mathrm{E}_{\text {equity }}(a)$, the value of equivalent wealth in Table 2, is a critical determinant of whether contributing to a TDA raises or lowers retirement wealth. When $\mathrm{E}_{\text {equity }}(a)>(1-\tau)$, a potential contributor raises his or her net-of-tax wealth by contributing to the taxdeferred account. If the tax on TDA withdrawals exceeds the ordinary income tax rate, or if equity returns are taxed at a rate below the ordinary income tax rate, one can construct examples in which $\mathrm{E}_{\text {equity }}(a)<(1-\tau)$ for plausible values of $\mathrm{A}$, so contributing to a TDA would not be a net-of-tax wealth-maximizing strategy for an eligible household. Whether such configurations of tax rates and investment horizons apply to many households is an open issue. They are particularly unlikely, as noted above, when contributions to the TDA are matched by an employer.

The relative valuation calculations in Table 2 do not address the riskiness of equity returns. When asset returns are uncertain, the income tax provides a form of insurance, reducing the return in favorable states of nature and, through the offsetting of capital gains and capital losses and the prospect of using some losses to offset other income, potentially raising the return in unfavorable states of nature. The opportunities for tax loss trading and relate d behaviors in taxable accounts but not in tax-deferred accounts, described for example in Poterba (2002), can affect the relative value of equity assets held in the two settings. This could usefully be addressed in further work.

3. Empirical Evidence on Tax-Deferred Asset Holders and Their Investments

The analysis in Tables 1 and 2 compares the value of a dollar held in either a bond, or in a stock, in a TDA and in a taxable account. In practice, many investors hold both stocks and bonds in their tax-deferred account, and fail to satisfy some of the "asset location" precepts identified in Shoven (1999). While Amromin (2002) and Bergstresser and Poterba (forthcoming) raise questions about whether investors make tax-minimizing decisions when they decide how to allocate TDA and non-TDA assets, the present analysis assumes that individuals would hold the same mix of assets 
inside and outside their TDA. In this case, it is natural to construct an average equivalent taxable wealth as a weighted average of the equivalent taxable wealth values for bonds and for stocks, with weights equal to their portfolio shares. This leads naturally to the search for data on TDA allocation patterns, as well as for information on investment horizons.

This section uses data from the 1998 Survey of Consumer Finances to provide an empirical foundation for the calculations regarding equivalent taxable values. The SCF data provide information on the age distribution of holdings in tax-deferred accounts, the asset mix in these accounts, and, with some imputations, on the marginal tax rates of the households that hold assets in tax-deferred accounts. Essentially all of the TDA assets in the 1998 survey are held in accounts for which taxes will be due at the time of withdrawal. Data from the 2001 and subsequent Surveys of Consumer Finance would be more difficult to use for this purpose, because it does not distinguish between TDA assets in Roth IRAs, traditional IRAs, 401(k) plans, and 403(b) accounts, even though the deferred taxes may differ across these accounts.

The 1998 SCF, which is described by Kennickell, Starr-McCluer, and Surette (2000), sampled 4309 households, with 2813 in the random sample and 1496 in the stratified random sample that overweighted those with high incomes or net worth. By combining an area probability sample with a highincome oversample, the SCF provides accurate information on broad population characteristics, while also offering in-depth information on the households that hold a disproportionate share of financial assets and net worth. Four households are excluded from the public use dataset due to disclosure concerns, leaving a sample with 4305 observations. One fourth of the households in the survey have net worth of over a million dollars. The tabulations presented below weight the various observations in the survey by their sampling weights so that the reported statistics should be representative of the U.S. population. The value of TDA assets equals the sum of assets held in 401(k)s, 403(b)s, IRAs, and supplemental retirement accounts (SRAs). Some assets in some traditional defined contribution plans 
that do not fall into these categories are excluded, since some of these plans may not allow participants much control over their asset allocation decisions.

\subsection{The Age Distribution of Holdings for Tax-Deferred Accounts}

The equivalent wealth calculations in Tables 1 and 2 are very sensitive to assumptions about the deferral horizon. Since individuals must begin to withdraw assets from their tax-deferred accounts at age $701 / 2$, and many take some distributions as early as age $591 / 2$, the age distribution of account owners is likely to provide key insights on the accumulation period for TDA assets.

Table 3 presents information on the age distribution of TDA holdings. The table presents both the age distribution of account holders, weighting each account holder equally, and the age distribution of account balances, in which each account holder is weighted by the value of their account. In each case there is a column for the marginal distribution of account holders or assets by age, as well as a cumulative distribution column showing the percentage of assets held by investors who are younger than the indicated age group. The data show that nearly half of all assets in TDAs are held by individuals in households where the household head is at least 55 years of age. Only one quarter of the assets are held by households headed by someone under the age of 45 . The distribution of accounts is quite different from the distribution of account balances, with almost half of the accounts held by households under the age of 45 . The substantial concentration of assets in TDAs held by households near retirement age suggests that only a modest fraction of current assets are likely to be held by households with very long retirement accumulation horizons.

\subsection{Asset Allocation Patterns in Tax-Deferred Accounts}

Table 4 presents information on the asset allocation mix in TDAs, again reporting both the percentage of account holders with particular allocations as well as the percentage of assets in accounts with different valuations. The table shows that more than half of all the assets in taxdeferred accounts are held in accounts with an equity allocation of more than 80 percent. Less than a quarter of TDA assets are held in accounts with an equity allocation of less than 20 percent. On 
average, accounts with a high allocation to equities were larger than accounts with more balanced allocations. Fifty-five percent of TDA assets were held in accounts with equity holdings of more than 80 percent. These accounts comprised 45 percent of the total set of accounts.

\subsection{Distribution of Marginal Tax Rates}

Another key parameter in the equivalent wealth calculation is the marginal tax rate on ordinary income. Table 5 presents the distribution of these marginal tax rates, again both weighting all account holders equally as well as weighting account-holders by their overall balances. The marginal income tax rate for SCF households is imputed using an algorithm developed in Poterba and Samwick (2003). It determines the household's marginal tax rate on the first dollar of interest income, after setting the other components of household capital income to zero. This procedure avoids a potential endogeneity between the structure of the household portfolio and the estimated marginal tax rate. The SCF contains only limited information on deductions that households might claim on their income taxes, so there is some imprecision in the estimated marginal tax rates.

Table 5 shows that there are substantial differences between the marginal tax rate distributions weighted by TDA assets and weighted by TDA account holders. While five percent of all TDA holders were facing ordinary income tax rates of 39 percent or higher, 24 percent of all TDA assets were held by these taxpayers. Similarly, while 44 percent of account holders had tax rates of fifteen percent or lower, this group accounted for only 15 percent of TDA assets. The median dollar in a TDA is held by a taxpayer in the 28 percent income tax bracket. These statistics provide some insight on the relevant marginal tax rates to consider in equivalent wealth calculations. The finding that assets within TDAs are skewed toward higher marginal tax rate households reinforces Joulfaian and Richardson's (2001) finding that higher marginal tax rate households are more likely to participate in tax-deferred saving programs.

3.4 Summary Equivalent Wealth Calculations 
The information in Tables 3 through 5 provides only limited insight on the relative valuation of assets held in TDAs and outside these accounts. To combine all of the determinants of equivalent wealth, one needs to determine the current marginal income tax rate for a household, make an assumption about the household's retirement investment horizon, and compute a weighted average of the equity and debt equivalent wealth measures with weights equal to the relative asset holdings in the two asset classes. Table 6 presents the results of this calculation. The table is divided into four horizontal panels. The first two correspond to the 1998 tax rate environment, and assume that the marginal tax rate on ordinary income remains constant during the accumulation and the withdrawal period. These panels set this marginal tax rate equal to the one that is estimated from current household income flows. They assume an effective capital gains tax rate of 10 percent, which is half of the top statutory rate on long-term gains. The reduction in the effective capital gains tax rate, relative to the statutory rate, reflects the impact of deferral and possible basis step-up at death. The lower two panels are designed to capture the potential impact of JGTRRA by reducing the dividend tax rate to 15 percent, while assuming that the ordinary income tax rate applies to interest income and to withdrawals from the TDA. Since JGTRRA also reduced the top capital gains tax rate on longterm gains from corporate stock to 15 percent, the effective capital gains tax rate for the JGTRRA calculations is set to 7.5 percent. The calculations in the lower two panels again assume that the ordinary income tax rate remains constant for the duration of the accumulation in the TDA.

Table 6 presents results for two possible dates of retirement income withdrawals, age 70 and age 80 . The first describes someone who chooses to withdraw the full balance of their tax-deferred account when they reached the beginning of the minimum distribution period, while the second approximates the longer distribution horizon for someone who uses minimum distributions, possibly in conjunction with a bequest that allows a beneficiary to further extend the distribution horizon for TDA assets. 
Table 6 computes equivalent wealth values under two assumptions about rates of return. In columns one and two, bonds are assumed to yield six percent, while equities have a nine percent nominal return. Equities are assumed to have a dividend yield of two percent and to generate a seven percent nominal return in the form of capital gains. The second return scenario assumes that bonds yield four percent interest while stocks continue to generate returns of nine percent. Because the value of assets in a TDA relative to assets outside these accounts is increasing in the rate of return assumption, the first set of assumptions generates a higher value for TDA assets.

Table 6 presents information on the weighted-average equivalent wealth by age groups, as well as for all households headed by someone under the age of 70 . The entries in the first and third columns weight all households with TDAs equally. The entries in the second and fourth columns show the weighted-average equivalent wealth value with households weighted by the TDA holdings. In both cases, the equivalent wealth value for a household is a weighted value of the bond and stock equivalent wealth estimates, with weights equal to the value of each type of asset.

The results in the upper panel, for the pre-JGTRRA situation, show that when bonds are assumed to yield six percent, the average wealth equivalent is 0.907 when retirement assets are assumed to be drawn down at age 70 , and 0.989 when the draw-down is assumed to occur at age 80 . These values correspond to the TDA-asset-weighted averages. The use of advanced ages, such as 80 , for the withdrawal horizon is justified in the next section. When bonds are assumed to yield four percent, the equivalent wealth value assuming withdrawal at age $70(80)$ is $0.873(0.935)$.

Table 6 also presents results for various age categories. These results illustrate how the age of the household head affects the estimate of the equivalent wealth. In the higher-return scenario, column two, the average wealth equivalent declines from 1.075 for households under the age of 35 to 0.748 for households over the age of 65 . This is a reflection of the changing accrual horizon for households at different ages. In the lower return case, column four, the analogous values are 1.011 for those under 35 and 0.744 for those over the age of 65 . 
When the tax rate assumptions are closer to the provisions of JGTRRA than to the preJGTRRA setting, the value of TDA assets declines relative to assets held outside these accounts. In the second column, for example, the weighted average equivalent wealth value, assuming a bond return of six percent, drops from 0.907 to 0.865 when withdrawals are assumed to occur at age 70 , and from 0.989 to 0.930 with withdrawal at age 80 . With lower bond returns, the relative value of the TDA assets is lower still, 0.830 with withdrawal at 70 and 0.876 with withdrawal at 80 .

The results in Table 6 suggest that for the average dollar currently held in a TDA, the cost of deferred taxes is somewhat greater than the additional value created by prospective accumulation at pre-tax rates of return. While the relative value of a dollar held in a TDA and a dollar held in a taxable account is sensitive to various assumptions about rates of return and deferral horizons, in most cases the weighted average value of a dollar of TDA assets is at least ninety percent of the value of comparable assets held outside the TDA, viewed from the perspective of retirement income support. These calculations imply that for the household sector as a whole, the value of retirement income support that current TDA holdings will provide is somewhat less than the value of support that would be provided if the same assets were held outside the tax-deferred setting.

\section{How Long is the Deferral Horizon? Analyzing Minimum Distribution Rules}

The relative value of assets inside and outside a tax deferred account depends on the horizon over which the account holder plans to accumulate assets. Yet there is very little information on the pattern of withdrawals from existing TDAs, and consequently little data on actual deferral horizons. Individuals can begin to draw down their tax-deferred balances at age 591/2 without penalty, and they must begin to take withdrawals by age $70 \frac{1}{2}$. The assumptions of withdrawalat age 70 and age 80 in Table 6 were designed to describe retirement savers who attempt to preserve the value of their taxdeferred assets for as long as possible. This section considers how minimum distribution requirements may affect the individual's deferral horizon. 
To ensure that contributors do not use tax-deferred accounts to completely avoid taxation of capital income, account holders over the age of $701 / 2$ face minimum distribution requirements (MDRs). The required distributions are determined by the age of the account holder and potentially by the age of the beneficiary who would inherit the account if the account holder were to die. MDRs limit the potential for taxpayers to accumulate assets in TDAs without ever paying taxes on the inside build-up. They are specified as an age-dependent fraction of the account balance.

One way to summarize their impact of MDRs on individuals who wish to defer withdrawals from TDAs for as long as possible involves computing the average number of years that assets will remain in the TDA before withdrawal. This can be illustrated by considering the case of an individual who reaches age 701/2 with one dollar in a TDA. Assume that the assets earn a return of $r$, and let $\mathrm{m}(a)$ denote the MDR at age a, as a percentage of the TDA balance at the end of the previous year. Let the account value at the end of the year when the account-holder celebrates his $a$ th birthday be $\mathrm{D}(a)$. If the account holder dies at age $\mathrm{p}$ and the entire TDA balance is withdrawn in the year of death, then the weighted-average age at which distributions are taken, $\mathrm{Y}(\mathrm{p})$, with each age weighted by the amount of distribution paid out, is:

$$
\mathrm{Y}(\mathrm{p})=\left[\Sigma_{\mathrm{a}=70, \mathrm{p}}\{\mathrm{a} * \mathrm{~m}(\mathrm{a}) * \mathrm{D}(\mathrm{a}-1)\}+\mathrm{p} * \mathrm{D}(\mathrm{p}-1)\right] /\left[\Sigma_{\mathrm{a}=70, \mathrm{p}}\{\mathrm{m}(\mathrm{a}) * \mathrm{D}(\mathrm{a}-1)\}+\mathrm{D}(\mathrm{p}-1)\right] .
$$

The account value evolves from one year to the next according to the recursion

$$
\mathrm{D}(\mathrm{a})=(1+\mathrm{r}) * \mathrm{D}(\mathrm{a}-1)-\mathrm{m}(\mathrm{a}) * \mathrm{D}(\mathrm{a}-1)
$$

Assuming that all TDA assets are withdrawn in the year when the account holder dies is a conservative assumption. It understates the potential opportunities for tax-deferred accumulation. With efficient estate planning, assets can remain in a TDA for many years after the death of the original contributor.

Equation (11) measures the duration of the withdrawals for an individual who dies at age p. For an individual who begins distributions at age $701 / 2$, however, age at death is unknown, and can 
be described by probability distribution of potential dates of death conditional on reaching age 70 . If $\mathrm{f}(\mathrm{p})$ is the probability of death at age $\mathrm{p}$, then the expected duration of TDA payouts, is

$$
\mathrm{E}(\mathrm{Y})=\Sigma_{\mathrm{p}} \mathrm{f}(\mathrm{p}) * \mathrm{Y}(\mathrm{p})
$$

Remaining life expectancy is defined as $\Sigma_{\mathrm{p}} \mathrm{f}(\mathrm{p}) *(\mathrm{p}-70)$, and since $\mathrm{m}(70)$ is equal to the reciprocal of this life expectancy, there is a close link between $f(p)$ and the MDR.

The expected duration of TDA payouts in (13) provides a tractable way of measuring how long assets will be held in a TDA if the account holders follow minimum distribution strategies. The expected duration will depend on the interest rate on TDA assets, which determines the relative amount in the TDA at different ages, on the MDR schedule, and on the mortality distribution. The expected duration is a measure of the time until withdrawal of the average dollar in a TDA, not the last dollar withdrawn from such an account.

Table 7 reports the minimum distribution requirement, as a percentage of TDA value, for individuals who have an Individual Retirement Account. Special rules apply to those IRA holders whose beneficiary is a spouse who is more than ten years younger than the account holder; the MDRs in Table 7 do not apply in that case. Table 7 also shows the mortality distribution, conditional on reaching age 70 , for men and for women. The table is capped at an age of 105 , an age at which only 0.2 percent of the men and 0.6 percent of women who reach age 70 are expected to be alive. The third and fourth columns of the table show the survival probabilities for men and for women who reach age 70. The data show that for a married couple in which both spouses are 70 , there is more than a fifty percent probability that at least one of the spouses will reach age 90 .

The last two columns in Table 7 show the distribution of dates of death for both men and women. This corresponds to $\mathrm{f}(\mathrm{p})$ in the foregoing calculations. The age with the highest number of deaths among those who reach age 70 is 85 for men, and 90 for women. The mortality distributions apply to the population at large, not for the set of households that have TDAs. There is a negative 
relationship between socio-economic status and mortality rates, which suggests that the reported survivor table may understate the longevity of those with tax-deferred assets.

The horizon over which withdrawals can be made depends upon how long the account holder lives, and on the way the TDA is transferred to the account holder's beneficiaries. Individual Retirement Accounts typically provide retirement savers with the greatest flexibility in managing the transfer of wealth to survivors, and provide opportunities to stretch the withdrawal period over a long horizon to maximize the benefits of tax-deferred accumulation. If the beneficiary is the spouse of the account holder, then the decedent's IRA can be rolled over into an IRA for the beneficiary spouse. The spouse can then draw down assets in the IRA according to the general rules that govern distributions. For example, if the IRA account holder dies at age 78, and the beneficiary spouse is 68, the spouse can roll the IRA balance into her IRA, and make no distributions until she turns $701 \frac{1}{2}$. She can then begin to draw down minimum distributions until her death, at which point her residual balance could be transferred to her beneficiary. This underscores the conservative nature of the assumption in equation (11) that all remaining assets are withdrawn when the account-holder dies.

If the beneficiary of an IRA is someone other than the account holder's spouse, then withdrawals from the IRA must be taken at least as quickly as a minimum distribution table calculated using the life expectancy of the beneficiary at the time of the IRA transfer would require. If the beneficiary is a grandchild of the account holder, for example, this could provide for a very low rate of initial withdrawal, thereby allowing the assets to continue to accumulate at the pre-tax rate of return for many years after the death of the account accumulator. Slott (2002) provides a detailed description of strategies that permit extending the period of tax deferral beyond the lifetime of the account accumulator.

To illustrate the concept of the expected duration of withdrawals from an IRA, Table 8 reports calculations based on equations (11) through (13). The calculations describe the stream of payouts for a man, or a woman, reaching age $70 \frac{1}{2}$ with an IRA, and taking minimum distributions 
from that age until death. The table considers three different cases, with returns of four, six, and eight percent on the assets in the IRA. The entries in the first and third rows of the table embody the conservative assumption that all of the assets remaining in the IRA at the time of the accountholder's death are distributed in the year of death. The second and fourth rows assume that the assets are transferred to a spouse and that the duration of withdrawals by the beneficiary is four years beyond the time of transfer. This is likely to substantially understate the actual addition to the period of tax deferral for the IRA assets.

Table 8 shows that the average age at which withdrawals are made is over 80 for all of the cases considered. This age is nearly 85 for the cases involving female account holders and the assumption that the transfer at death adds four additional years to the average date of payout. Allowing for transfers to younger beneficiaries or for spouses who draw down their assets slowly would further le ngthen the accumulation period. The table provides some support for the use of 80 as an accumulation horizon in the earlier tables, since it suggests that for a TDA holder who reaches age 70 , and tries to preserve the balance in the account, this is a pla usible lower bound on the average date for distributions.

\section{$\underline{\text { 5. Conclusions }}$}

This paper presents new evidence on the relationship between the amount of retirement consumption that can be supported by a dollar held in a tax-deferred account, such as a traditional IRA or a 401(k) plan, and a dollar held in a taxable account. Calculations based on the age distribution of TDA holdings, the mix of debt and equity securities in these accounts, and the marginal tax rates of the TDA holders in the late 1990s suggest that the deferred taxes on these accounts exceed the value of future inside-build up. These calculations imply that the household sector in aggregate would require a smaller stock of taxable investment assets outside tax-deferred accounts to deliver the same resources at retirement as the current stock of TDA assets will provide. This finding, which is based on the tax rates that were in effect prior to the 2003 tax reform, is 
strengthened by the impact of the Jobs and Growth Tax Relief Reconciliation Act of 2003. By lowering the tax rate on dividends and capital gains on corporate stock held outside tax-deferred accounts, while preserving the taxation at ordinary income rates on withdrawals from tax-deferred accounts, JGTRRA reduced the value of a dollar held in a tax-deferred account relative to a dollar held in a traditional taxable account.

The present analysis illustrates one approach to valuing a dollar of assets held in a taxdeferred account. The approach is forward-looking, and it calculates the value of retirement resources that can be supported by a dollar of TDA assets under various assumptions about account accumulation patterns and withdrawal behavior. This approach offers insights on the tradeoffs between TDA assets and other assets on the household balance sheet, viewed from the perspective of retirement support. It is in the same spirit as many discussions of the adequacy of retirement saving that focus on the future value of pension assets and Social Security. This approach is different from the backward-looking approach that many studies have used to evaluate the net saving effect of contributions to targeted retirement saving programs. Those studies ask how much past consumption was foregone in the process of generating the current asset balance in tax deferred accounts. Both the forward- and the backward-looking approaches can be useful, but it is important to recognize that they are directed at answering different questions.

The numerical results in this study underscore the sensitivity of the relative value calculation to several key assumptions, and they point to the need for additional empirical research on the relevant parameters. For example, the withdrawal patterns from both Individual Retirement Accounts and other tax-deferred accounts are a key determinant of the effective investment horizon for TDA assets. Some studies, such as Burman, Gale, and Weiner (2001), Burman, Coe, and Gale (1999), and Sabelhaus (2000), have begun to investigate withdrawal behavior, but further data analysis is needed. Information on the fraction of households with tax-deferred accounts that does not make any withdrawals before the age at which minimum distributions begin would be extremely 
valuable. So would data on the share of households that begins to take distributions at $591 / 2$, and possibly draws down all of the assets before reaching age 70. Similarly, there is no information on the pattern of TDA transfers that occur at death or on the fraction of bequeathable TDAs, such as IRAs, that are bequeathed to a surviving spouse. A related data need concerns the pattern of marginal tax rates that households face over their lifetimes. Such panel data on tax rates would make it possible to consider the substantive importance of higher marginal tax rates in retirement than over the course of the working life. Yet another unresolved question concerns the extent to which individuals understand the potential tax liabilities that they face when they withdraw TDA assets, and the implications of deferred taxes for the riskiness and valuation of TDA and non-TDA assets.

The analysis developed here could be expanded in a number of directions. It could consider factors besides income taxes that may affect the relative valuation of assets inside and outside retirement accounts. For example, the current rules governing eligibility for financial aid create incentives to accumulate assets within tax-deferred accounts. For some households the implicit marginal tax rates associated with financial aid programs substantially affect the returns to building up wealth outside retirement accounts. The analysis could also be extended to allow for the possibility of pre-retirement withdrawals from tax-deferred accounts, with the attendant possibility that the household would pay penalty taxes on such distributions. It could also include an analysis of Roth IRAs, which differ from the tax-deferred accounts considered here because there are no taxes due when assets are withdrawn. The relative value of a dollar he ld in a Roth IRA could be compared with the value of a dollar held in a taxable account.

The framework could also be generalized to evaluate the long-term wealth generation potential of other long-term household investments, such as home ownership. The returns from investments in owner-occupied housing are taxed differently than the returns to financial assets such as bonds and certificates of deposit, so one could relate the amount of retirement consumption that could be sustained by a dollar of housing equity to the amount that could be sustained by a dollar 
invested in financial assets. Unlike the calculations presented in this paper, which focus on the same assets held inside or outside tax-deferred accounts, estimates of the retirement wealth contribution of different asset categories would depend on the assumed rates of return on the various assets.

This paper has focused on the microeconomic analysis of tax-deferred accounts, and the problem of valuing deferred taxes from the standpoint of a household. Deferred taxes associated with withdrawals from retirement accounts may also have important consequences for aggregate economic activity. Boskin (2003) recognizes that withdrawals from retirement accounts will have a substantial positive effect on federal income tax collections when the Baby Boom cohort retires, and argues that these revenue effects are not well captured by current forecasts. Whether these revenue flows will narrow currently-projected budget deficits is an open issue. Auerbach, Gale, and Orszag (2003) claim that most of the revenues from TDA withdrawals are already included in long-term revenue projections, while also noting that reductions in the future tax rates that apply to these distributions would have substantial negative effects on federal revenues. 


\section{REFERENCES}

Amromin, Gene (2002), "Portfolio Allocation Choices in Taxable and Tax-Deferred Accounts: An Empirical Test of Tax Efficiency," mimeo, Federal Reserve Board of Governors.

Auerbach, Alan, William Gale, and Peter Orszag (2003). "Reassessing the Fiscal Gap: Why TaxDeferred Saving Will Not Solve the Problem," Tax Notes (July 28).

Bergstresser, Daniel and James Poterba (forthcoming). "Asset Allocation and Location Decisions: Evidence from the Survey of Consumer Finances," Journal of Public Economics.

Boskin, Michael (2003), "Deferred Taxes in the Public Finances,” mimeo, Stanford University Department of Economics.

Burman, Leonard, Norma Coe, and William Gale (1999), "Lump Sum Distributions from Pension Plans: Recent Evidence and Issues for Policy and Research,” National Tax Journal, 52 (September), 553-562.

Burman, Leonard, William Gale, and David Weiner (2001). “The Taxation of Retirement Sa ving: Choosing Between Front-Loaded and Back-Loaded Options,” National Tax Journal, 54 (September), 689-702.

Campbell, John (2001). "Forecasting U.S. Equity Returns in the $21^{\text {st }}$ Century," in Social Security Advisory Board, Estimating the Real Rate of Return on Stocks Over the Long Term (Washington: Social Security Advisory Board).

Crain, Terry and Jeffrey Austin (1998). “An Analysis of the Tradeoff Between Tax Deferred Earnings and Preferential Capital Gains,” Financial Services Review 6 (4), 227-242.

Dia mond, Peter (2001). "What Stock Market Returns to Expect for the Future?” in Social Security Advisory Board, Estimating the Real Rate of Return on Stocks Over the Long Term (Washington: Social Security Advisory Board).

Engen, Eric, and William Gale (2000). "The Effect of 401(k) Plans on Household Wealth: Differences Across Earnings Groups.” NBER Working Paper 8032. 
Engen, Eric, William Gale, and J. Karl Scholz (1996), "The Illusory Effects of Saving Incentives on Saving," Journal of Economic Perspectives 10 (Fall), 113-138.

Gale, William (1998). "The Effects of Pensions on Household Wealth: A Reevaluation of Theory and Evidence," Journal of Political Economy 106 (August), 706-723.

Gokhale, Jagadeesh, and Laurence Kotlikoff (2003). "Who Gets Paid to Save?," in J. Poterba, ed.,

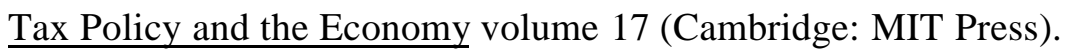

Gokhale, Jagadeesh, Laurence Kotlikoff, and Todd Neumann (2001). "Does Participating in a 401(k) Raise Your Lifetime Taxes?,” NBER Working Paper 8341.

Joulfaian, David and David Richardson (2001). "Who Takes Advantage of Tax-Deferred Saving Programs? Evidence from Federal Income Tax Data,” National Tax Journal54 (September), 669-688.

Kennickell, Arthur B., Martha Starr-McCluer, and Brian Surette. 2000. "Changes in U.S. Family Finances at the End of the 1990s: Results from the 1998 Survey of Consumer Finances." Federal $\underline{\text { Reserve Bulletin (January). }}$

Poterba, James. 1998. 'The Rate of Return to Corporate Capital and Factor Shares: New Estimates Using Revised National Income Accounts and Capital Stock Data,” Carnegie-Rochester Conference Series on Public Policy 48, 211-246.

Poterba, James. 2002. "Taxation, Risk-Taking, and Portfolio Behavior," in A. Auerbach and M. Feldstein, Handbook of Public Economics: Volume 3 (Amsterdam: North Holland, 2002), 1109-1171.

Poterba, James and Andrew Samwick (2003), “Taxation and Household Portfolio Composition: Evidence from Tax Reforms in the 1980s and 1990s." Journal of Public Economics.

Poterba, James, Steven Venti, and David Wise. (1996). "How Retirement Saving Programs Increase Saving," Journal of Economic Perspectives 10 (Fall), 91-112. 
Poterba, James, Steven Venti, and David Wise (1998). "Personal Retirement Saving Programs and Asset Accumulation: Reconciling the Evidence," in D. Wise, ed., Frontiers of the Economics of Aging (Chicago: University of Chicago Press), 23-106.

Poterba, James, Steven Venti, and David Wise. (2000) "Saver Behavior and 401(k) Retirement Wealth," American Economic Review 90 (May), 297-302.

Reichenstein, William. (1998). "Calculating a Family’s Asset Mix,” Financial Services Review 7, 195-206.

Reichenstein, William and William Jennings. (2003). Integrating Investments and the Tax Code. (Hoboken, NJ: John Wiley and Sons).

Sabelhaus, John. (2000), "Modeling IRA Accumulation and Withdrawals," National Tax Journal, 53 (December, Part 1), 865-875.

Shoven, John B. (1999). "The Location and Allocation of Assets in Pension and Conventional Savings Accounts," NBER Working Paper 7007.

Shoven, John (2001). "What Are Reasonable Long-Run Rates of Return to Expect on Equities?” in Social Security Advisory Board, Estimating the Real Rate of Return on Stocks Over the Long Term (Washington: Social Security Advisory Board).

Sibley, Mike (2002). "On the Valuation of Tax-Advantaged Retirement Accounts." Financial Services Review 11, 233-251.

Slott, Ed (2003). The Retirement Savings Time Bomb and How to Defuse It (New York: Viking Press). 
Table 1: Equivalent Taxable Wealth Calculations for Bond Investments

\begin{tabular}{|c|c|c|c|c|c|c|c|c|c|}
\hline \multirow{2}{*}{$\begin{array}{l}\text { Years until } \\
\text { Withdrawal }\end{array}$} & \multicolumn{3}{|l|}{$\tau=.15$} & \multicolumn{3}{|l|}{$\tau=.28$} & \multicolumn{3}{|l|}{$\tau=.36$} \\
\hline & $\mathrm{r}=.04$ & $\mathrm{r}=.06$ & $\mathrm{r}=.08$ & $\mathrm{r}=.04$ & $\mathrm{r}=.06$ & $\mathrm{r}=.08$ & $\mathrm{r}=.04$ & $\mathrm{r}=.06$ & $\mathrm{R}=.08$ \\
\hline & \multicolumn{9}{|c|}{ TDA Withdrawal Tax Rate Equal to Tax Rate on Accumulating Taxable Assets } \\
\hline 0 & 0.850 & 0.850 & 0.850 & 0.720 & 0.720 & 0.720 & 0.640 & \begin{tabular}{l|l}
0.640 & \\
\end{tabular} & 0.640 \\
\hline 10 & 0.903 & 0.930 & 0.958 & 0.805 & 0.852 & 0.900 & 0.739 & 0.794 & 0.853 \\
\hline 20 & 0.958 & 1.018 & 1.081 & 0.901 & 1.008 & 1.127 & 0.854 & 0.986 & 1.139 \\
\hline 30 & 1.018 & 1.113 & 1.218 & 1.008 & 1.192 & 1.410 & 0.986 & 1.223 & $\mathbf{1 . 5 1 8}$ \\
\hline 40 & 1.081 & 1.218 & 1.374 & 1.267 & 1.410 & 1.764 & 1.139 & 1.518 & 2.025 \\
\hline \multirow[t]{2}{*}{50} & $\mathbf{1 . 1 4 7}$ & 1.333 & 1.549 & 1.260 & 1.668 & 2.207 & 1.315 & 1.885 & 2.701 \\
\hline & \multicolumn{9}{|c|}{ TDA Withdrawal Tax Rate $=.15$} \\
\hline 0 & 0.850 & 0.850 & 0.850 & 0.850 & 0.850 & 0.850 & 0.850 & 0.850 & 0.850 \\
\hline 10 & 0.903 & 0.930 & 0.958 & 0.951 & 1.005 & 1.063 & 0.981 & 1.055 & 1.134 \\
\hline 20 & 0.958 & 1.018 & 1.081 & 1.063 & 1.189 & 1.330 & 1.134 & 1.309 & 1.512 \\
\hline 30 & 1.018 & 1.113 & 1.218 & 1.189 & 1.407 & 1.664 & 1.309 & 1.625 & 2.017 \\
\hline 40 & 1.081 & 1.218 & 1.374 & 1.330 & 1.664 & 2.082 & 1.512 & 2.017 & 2.690 \\
\hline \multirow[t]{2}{*}{50} & 1.147 & 1.333 & 1.549 & 1.488 & 1.969 & 2.605 & 1.746 & 2.503 & 3.588 \\
\hline & \multicolumn{9}{|c|}{ TDA Withdrawal Tax Rate $=$ Tax Rate on Accumulating Assets +.10} \\
\hline 0 & 0.750 & 0.750 & 0.750 & 0.620 & 0.620 & 0.620 & 0.540 & 0.540 & 0.540 \\
\hline 10 & 0.796 & 0.821 & 0.846 & 0.693 & 0.733 & 0.776 & 0.624 & 0.670 & 0.720 \\
\hline 20 & 0.846 & 0.898 & 0.953 & 0.776 & 0.868 & 0.970 & 0.720 & 0.832 & 0.961 \\
\hline 30 & 0.898 & 0.982 & 1.075 & 0.868 & 1.026 & 1.214 & 0.832 & 1.032 & 1.281 \\
\hline 40 & 0.953 & 1.075 & 1.212 & 0.970 & 1.214 & 1.519 & 0.961 & 1.281 & 1.709 \\
\hline 50 & 1.012 & 1.176 & 1.367 & 1.085 & 1.436 & 1.900 & 1.109 & 1.590 & 2.279 \\
\hline
\end{tabular}

Source: Author's calculations as described in the text. The marginal tax rate on ordinary income, such as interest income, is denoted by $\mathrm{t}$. 
Table 2: Equivalent Taxable Wealth Calculations for Stock Investments, Dividend Yield $=0.02, \mathrm{~g}=$ Expected Appreciation Rate

\begin{tabular}{|c|c|c|c|c|c|c|c|c|c|c|c|c|}
\hline \multirow{2}{*}{$\begin{array}{l}\text { Years Until } \\
\text { Withdrawal }\end{array}$} & \multicolumn{3}{|c|}{$\mathrm{t}_{\mathrm{div}}=.15, \mathrm{t}_{\mathrm{cg}}=.075, \mathrm{t}_{\text {ordinary }}=.15$} & \multicolumn{3}{|c|}{$\mathrm{t}_{\mathrm{div}}=.28, \mathrm{t}_{\mathrm{cg}}=.10, \mathrm{t}_{\text {ordinary }}=.28$} & \multicolumn{3}{|c|}{$\mathrm{t}_{\text {div }}=.36, \mathrm{t}_{\mathrm{cg}}=.10, \mathrm{t}_{\text {ordinary }}=.36$} & \multicolumn{3}{|c|}{$\mathrm{t}_{\mathrm{div}}=.15, \mathrm{t}_{\mathrm{cg}}=.075, \mathrm{t}_{\text {ordinary }}=.35$} \\
\hline & $\mathrm{g}=0.04$ & $g=0.07$ & 0.10 & 0.04 & 0.07 & 0.10 & 0.04 & 0.07 & 0.10 & 0.04 & 0.07 & 0.10 \\
\hline & \multicolumn{12}{|c|}{ TDA Withdrawal Tax Rate Equal to Ordinary Tax Rate } \\
\hline 0 & 0.850 & 0.850 & 0.850 & 0.720 & 0.720 & 0.720 & 0.640 & 0.640 & 0.640 & 0.650 & 0.650 & 0.650 \\
\hline 10 & 0.896 & 0.908 & 0.916 & 0.786 & 0.799 & 0.810 & 0.710 & 0.722 & 0.732 & 0.685 & 0.694 & 0.701 \\
\hline 30 & 0.972 & 0.985 & 0.992 & 0.905 & 0.922 & 0.930 & 0.845 & 0.861 & 0.869 & 0.743 & 0.753 & 0.758 \\
\hline 40 & 1.006 & 1.018 & 1.023 & 0.964 & 0.979 & 0.986 & 0.915 & 0.929 & 0.936 & 0.769 & 0.778 & 0.783 \\
\hline \multirow[t]{2}{*}{50} & 1.039 & 1.050 & 1.055 & 1.023 & 1.037 & 1.044 & 0.987 & 1.001 & 1.006 & 0.795 & 0.803 & 0.807 \\
\hline & \multicolumn{12}{|c|}{ TDA Withdrawal Tax Rate $=0.15$} \\
\hline 0 & 0.850 & 0.850 & 0.850 & 0.850 & 0.850 & 0.850 & 0.850 & 0.850 & 0.850 & 0.850 & 0.850 & 0.850 \\
\hline 10 & 0.896 & 0.908 & 0.916 & 0.928 & 0.944 & 0.956 & 0.943 & 0.959 & 0.972 & 0.896 & 0.908 & 0.916 \\
\hline 20 & 0.936 & 0.950 & 0.958 & 0.999 & 1.020 & 1.032 & 1.033 & 1.054 & 1.066 & 0.936 & 0.950 & 0.958 \\
\hline 40 & 1.006 & 1.018 & 1.023 & 1.138 & 1.156 & 1.164 & 1.215 & 1.234 & 1.243 & 1.006 & 1.018 & 1.023 \\
\hline \multirow[t]{2}{*}{50} & 1.039 & 1.050 & $\mathbf{1 . 0 5 5}$ & 1.208 & 1.225 & 1.232 & 1.311 & 1.329 & 1.336 & 1.039 & 1.050 & 1.055 \\
\hline & \multicolumn{12}{|c|}{ TDA Withdrawal Tax Rate $=$ Ordinary Income Tax Rate +0.10} \\
\hline 0 & 0.750 & 0.750 & 0.750 & 0.620 & 0.620 & 0.620 & 0.540 & 0.540 & 0.540 & 0.550 & 0.550 & 0.550 \\
\hline 10 & 0.791 & 0.801 & 0.809 & 0.677 & 0.688 & 0.697 & 0.599 & 0.609 & 0.617 & 0.580 & 0.587 & 0.593 \\
\hline 20 & 0.826 & 0.838 & 0.845 & 0.729 & 0.744 & 0.753 & 0.656 & 0.669 & 0.677 & 0.606 & 0.615 & 0.620 \\
\hline 30 & 0.858 & 0.869 & 0.875 & 0.780 & 0.794 & 0.801 & 0.713 & 0.726 & 0.733 & 0.629 & 0.637 & 0.642 \\
\hline 40 & 0.888 & 0.898 & 0.903 & 0.830 & 0.843 & 0.849 & 0.772 & 0.784 & 0.789 & 0.651 & 0.659 & 0.662 \\
\hline 50 & 0.917 & 0.927 & 0.931 & 0.881 & 0.893 & 0.899 & 0.833 & 0.844 & 0.849 & 0.672 & 0.679 & 0.683 \\
\hline
\end{tabular}

Source: Author's calculations as described in the text. 
Table 3: Age Distribution of Tax-Deferred Account Ownership, 1998 SCF

\begin{tabular}{|c|c|c|c|c|}
\hline \multirow[t]{2}{*}{ Age of Household Head } & \multicolumn{2}{|c|}{$\begin{array}{l}\text { Percentage of Tax-Deferred } \\
\text { Account Holders }\end{array}$} & \multicolumn{2}{|c|}{$\begin{array}{l}\text { Percentage of Assets Held in } \\
\text { Tax-Deferred Accounts }\end{array}$} \\
\hline & Marginal & Cumulative & Marginal & Cumulative \\
\hline$<25$ & 5.1 & 5.1 & 0.6 & 0.6 \\
\hline $25-29$ & 8.9 & 14.0 & 1.9 & 2.5 \\
\hline $30-34$ & 9.3 & 23.3 & 4.9 & 7.4 \\
\hline $35-39$ & 11.5 & 34.8 & 7.0 & 14.4 \\
\hline $40-44$ & 11.8 & 46.6 & 11.4 & 25.8 \\
\hline $45-49$ & 10.2 & 56.8 & 11.6 & 37.4 \\
\hline $50-54$ & 9.0 & 65.8 & 13.5 & 50.9 \\
\hline $55-59$ & 7.7 & 73.5 & 12.8 & 63.7 \\
\hline $60-64$ & 5.2 & 78.7 & 10.1 & 73.8 \\
\hline $65-69$ & 5.9 & 84.6 & 8.8 & 82.6 \\
\hline $70-74$ & 5.4 & 90.0 & 7.8 & 90.4 \\
\hline $75+$ & 10.2 & 100.0 & 9.7 & 100.0 \\
\hline
\end{tabular}

Source: Author's tabulation based on data in the 1998 Survey of Consumer Finances.

Table 4: Asset Allocation in Taxable and Tax-Deferred Accounts, 1998 SCF

\begin{tabular}{|l|r|r|}
\hline $\begin{array}{l}\text { Percentage of Tax-Deferred } \\
\text { Assets Held in Stocks }\end{array}$ & $\begin{array}{l}\text { Percentage of Tax-Deferred } \\
\text { Account Holders }\end{array}$ & $\begin{array}{l}\text { Percentage of Assets Held in } \\
\text { Tax-Deferred Accounts }\end{array}$ \\
\hline$<20 \%$ & $25.4 \%$ & $20.2 \%$ \\
\hline $20-40$ & 3.6 & 4.6 \\
\hline $40-60$ & 23.5 & 17.1 \\
\hline $60-80$ & 2.5 & 3.1 \\
\hline $80+$ & 45.0 & 55.0 \\
\hline
\end{tabular}

Source: Author's tabulations from the 1998 Survey of Consumer Finances. All calculations are based on the universe of households with at least some assets in a tax-deferred account (TDA).

Table 5: Distribution of TDA Holders by Marginal Tax Rates, 1998 SCF

\begin{tabular}{|l|r|r|}
\hline $\begin{array}{l}\text { Marginal Tax Rate on Interest } \\
\text { Income (First Dollar Rate) }\end{array}$ & $\begin{array}{l}\text { Percentage of Tax-Deferred } \\
\text { Account Holders }\end{array}$ & $\begin{array}{l}\text { Percentage of Assets Held in } \\
\text { Tax-Deferred Accounts }\end{array}$ \\
\hline$<15 \%$ & $10.0 \%$ & $6.8 \%$ \\
\hline 15 & 33.9 & 8.3 \\
\hline $15-27$ & 9.1 & 14.2 \\
\hline $28-30$ & 35.7 & 32.1 \\
\hline $31-38$ & 6.2 & 14.5 \\
\hline $39-41$ & 3.1 & 11.1 \\
\hline$>41$ & 2.1 & 12.9 \\
\hline
\end{tabular}

Source: Author's tabulations from the 1998 Survey of Consumer Finances. All calculations are based on the universe of households with at least some assets in a tax-deferred account (TDA). 
Table 6: Weighted Average Equivalent Wealth in Taxable Accounts vs. TDAs, 1998 SCF

\begin{tabular}{|c|c|c|c|c|}
\hline \multirow[t]{2}{*}{ Age Subcategory } & \multicolumn{2}{|c|}{$\begin{array}{l}\text { Bond Return }=.06, \text { Stock Return }= \\
.09, \text { Dividend Yield }=.02\end{array}$} & \multicolumn{2}{|c|}{$\begin{array}{l}\text { Bond Return }=.04, \text { Stock Return }= \\
.09, \text { Dividend Yield }=.02\end{array}$} \\
\hline & $\begin{array}{l}\text { Participant- } \\
\text { Weighted }\end{array}$ & $\begin{array}{l}\text { Weighted by } \\
\text { TDA Assets }\end{array}$ & $\begin{array}{l}\text { Participant- } \\
\text { Weighted }\end{array}$ & $\begin{array}{l}\text { Weighted by } \\
\text { TDA Assets }\end{array}$ \\
\hline \multicolumn{5}{|c|}{$\begin{array}{l}\text { Assuming Ordinary Income Tax Rate Applies to Interest Income, Dividend Income, and } \\
\text { Withdrawals from Tax-Deferred Account, Capital Gains Taxed at } 10 \text { Percent }\end{array}$} \\
\hline & \multicolumn{4}{|c|}{ Asset Withdrawal at Age 70} \\
\hline$<35$ & 1.097 & 1.075 & 1.034 & 1.011 \\
\hline $35-44$ & 1.018 & 0.986 & 0.968 & 0.934 \\
\hline $45-54$ & 0.926 & 0.882 & 0.894 & 0.856 \\
\hline $55-64$ & 0.871 & 0.785 & 0.854 & 0.771 \\
\hline$>65$ & 0.856 & 0.748 & 0.851 & 0.744 \\
\hline \multirow[t]{2}{*}{ All Age Groups } & 0.977 & 0.907 & 0.937 & 0.873 \\
\hline & \multicolumn{4}{|c|}{ Asset Withdrawal at Age 80} \\
\hline$<35$ & 1.179 & 1.171 & 1.091 & 1.079 \\
\hline $35-44$ & 1.108 & 1.089 & 1.031 & 1.008 \\
\hline $45-54$ & 1.014 & 0.972 & 0.959 & 0.926 \\
\hline $55-64$ & 0.952 & 0.879 & 0.960 & 0.845 \\
\hline$>65$ & 0.913 & 0.830 & 0.916 & 0.817 \\
\hline All Age Groups & 1.052 & 0.989 & 0.993 & 0.935 \\
\hline \multicolumn{5}{|c|}{$\begin{array}{l}\text { Assuming Ordinary Income Tax Rate Applies to Interest Income and Withdrawals from Tax- } \\
\text { Deferred Account, Dividends Taxed at } 15 \text { Percent, Capital Gains Taxed at } 7.5 \text { Percent }\end{array}$} \\
\hline & \multicolumn{4}{|c|}{ Asset Withdrawal at Age 70} \\
\hline$<35$ & 1.064 & 1.014 & 1.002 & 0.950 \\
\hline $35-44$ & 0.983 & 0.928 & 0.932 & 0.876 \\
\hline $45-54$ & 0.894 & 0.838 & 0.862 & 0.812 \\
\hline $55-64$ & 0.858 & 0.763 & 0.841 & 0.748 \\
\hline$>65$ & 0.855 & 0.742 & 0.850 & 0.738 \\
\hline \multirow[t]{2}{*}{ All Age Groups } & 0.949 & 0.865 & 0.909 & 0.830 \\
\hline & \multicolumn{4}{|c|}{ Asset Withdrawal at Age 80} \\
\hline$<35$ & 1.138 & 1.093 & 1.051 & 1.002 \\
\hline $35-44$ & 1.061 & 1.011 & 0.984 & 0.930 \\
\hline $45-54$ & 0.967 & 0.905 & 0.913 & 0.860 \\
\hline $55-64$ & 0.929 & 0.835 & 0.893 & 0.801 \\
\hline$>65$ & 0.910 & 0.812 & 0.896 & 0.800 \\
\hline All Age Groups & 1.015 & 0.930 & 0.956 & 0.876 \\
\hline
\end{tabular}

Source: Authors' calculations as described in text. 
Table 7: Minimum Distribution Requirements and Mortality Distributions

\begin{tabular}{|c|c|c|c|c|c|}
\hline \multirow[t]{2}{*}{ Age } & \multirow[t]{2}{*}{$\begin{array}{l}\text { Minimum Distribution } \\
\text { Requirement (Percent } \\
\text { of Account Balance) }\end{array}$} & \multicolumn{2}{|c|}{$\begin{array}{l}\text { Survival } \\
\text { Probability (Given } \\
\text { Reached Age 70) }\end{array}$} & \multicolumn{2}{|c|}{$\begin{array}{l}\text { Percent of Individuals } \\
\text { Reaching Age } 70 \text { Who Die } \\
\text { at This Age }\end{array}$} \\
\hline & & Men & Women & Men & Women \\
\hline 71 & 0.038 & 1 & 1 & $0 \%$ & $0 \%$ \\
\hline 72 & 0.040 & 0.9697 & 0.9803 & 3.03 & 1.97 \\
\hline 73 & 0.041 & 0.9383 & 0.9595 & 3.14 & 2.08 \\
\hline 74 & 0.043 & 0.9058 & 0.9375 & 3.25 & 2.2 \\
\hline 75 & 0.044 & 0.8719 & 0.9142 & 3.39 & 2.33 \\
\hline 76 & 0.046 & 0.8366 & 0.8894 & 3.53 & 2.48 \\
\hline 77 & 0.048 & 0.7998 & 0.8631 & 3.68 & 2.63 \\
\hline 78 & 0.050 & 0.7614 & 0.8351 & 3.84 & 2.8 \\
\hline 79 & 0.052 & 0.7214 & 0.8056 & 4 & 2.95 \\
\hline 80 & 0.054 & 0.6797 & 0.7745 & 4.17 & 3.11 \\
\hline 81 & 0.057 & 0.6365 & 0.742 & 4.32 & 3.25 \\
\hline 82 & 0.060 & 0.592 & 0.7079 & 4.45 & 3.41 \\
\hline 83 & 0.063 & 0.5464 & 0.6722 & 4.56 & 3.57 \\
\hline 84 & 0.065 & 0.5003 & 0.6349 & 4.61 & 3.73 \\
\hline 85 & 0.069 & 0.4538 & 0.5961 & 4.65 & 3.88 \\
\hline 86 & 0.072 & 0.4076 & 0.5558 & 4.62 & 4.03 \\
\hline 87 & 0.076 & 0.3621 & 0.5141 & 4.55 & 4.17 \\
\hline 88 & 0.081 & 0.3178 & 0.4712 & 4.43 & 4.29 \\
\hline 89 & 0.085 & 0.2754 & 0.4275 & 4.24 & 4.37 \\
\hline 90 & 0.090 & 0.2354 & 0.3835 & 4 & 4.4 \\
\hline 91 & 0.095 & 0.1983 & 0.3396 & 3.71 & 4.39 \\
\hline 92 & 0.101 & 0.1644 & 0.2965 & 3.39 & 4.31 \\
\hline 93 & 0.106 & 0.1341 & 0.255 & 3.03 & 4.15 \\
\hline 94 & 0.114 & 0.1075 & 0.2157 & 2.66 & 3.93 \\
\hline 95 & 0.120 & 0.0846 & 0.1791 & 2.29 & 3.66 \\
\hline 96 & 0.128 & 0.0653 & 0.1164 & 1.93 & 6.27 \\
\hline 97 & 0.137 & 0.0494 & 0.091 & 1.59 & 2.54 \\
\hline 98 & 0.145 & 0.0366 & 0.0698 & 1.28 & 2.12 \\
\hline 99 & 0.154 & 0.0267 & 0.0525 & 0.99 & 1.73 \\
\hline 100 & 0.164 & 0.019 & 0.0388 & 0.77 & 1.37 \\
\hline 101 & 0.175 & 0.0133 & 0.0281 & 0.57 & 1.07 \\
\hline 102 & 0.189 & 0.0091 & 0.02 & 0.42 & 0.81 \\
\hline 103 & 0.200 & 0.0062 & 0.0139 & 0.29 & 0.61 \\
\hline 104 & 0.213 & 0.0041 & 0.0094 & 0.21 & 0.45 \\
\hline 105 & 0.227 & 0.0026 & 0.0062 & 0.15 & 0.32 \\
\hline
\end{tabular}

Source: Minimum distribution shares are calculated from IRS tables. Mortality statistics are drawn from Social Security Office of the Actuary publications. 
Table 8: Duration of Distributions from Individual Retirement Account, Assuming No Distributions Prior to Age 70 1/2

\begin{tabular}{|l|l|l|l|}
\hline \multirow{2}{*}{} & \multicolumn{3}{|c|}{ Rate of Return on IRA Assets } \\
\cline { 2 - 4 } & $\mathrm{R}=.04$ & $\mathrm{R}=.06$ & $\mathrm{R}=.08$ \\
\hline $\begin{array}{l}\text { Male Account Holder, Account } \\
\text { Liquidation at Death }\end{array}$ & 80.03 & 80.51 & 80.94 \\
\hline $\begin{array}{l}\text { Male Account Holder, Account } \\
\text { Liquidation at Death + 4 Years }\end{array}$ & 82.22 & 82.83 & 83.37 \\
\hline $\begin{array}{l}\text { Female Account Holder, Account } \\
\text { Liquidation at Death }\end{array}$ & 81.30 & 81.97 & 82.55 \\
\hline $\begin{array}{l}\text { Female Account Holder, Account } \\
\text { Liquidation at Death + 4 Years }\end{array}$ & 83.20 & 84.00 & 84.72 \\
\hline
\end{tabular}

Source: Author's calculations as described in the text. 